\title{
УДК:[632.4+582.28]:573.6.086 https://doi.org/10.53040/gppb7.2021.85 \\ АНТАГОНИСТИЧЕСКАЯ АКТИВНОСТЬ ЭНТОМОПАТОГЕННЫХ ГРИБОВ В ОТНОШЕНИИ ФИТОПАТОГЕННЫХ МИКРОМИЦЕТОВ
}

\author{
Янковская Е.Н., Войтка Д.В., Федорович М.В., Михнюк А.В. \\ РУП «Институт защиты растений», Минск, Беларусь \\ e-mail: helena-yan@yandex.ru
}

\begin{abstract}
The researches on evaluation the influence of entomopathogenic fungi of the genuses Beauveria, Isaria and Lecanicillium influence on phytopathogenic microorganisms Alternaria solani, Botrytis cinerea, Sclerotinia sclerotiorum, Rhizoctonia solani, Fusarium solani, Phytophtora alni are presented. The antifungal peculiarities of tested strains - a potential basis of complex action biological preparations for plant protection are shown in vitro. The highest level of antagonistic activity has been revealed in strains Beauveria brongniartii MX, Lecanicillium sp. aph and Isaria fumosorosea 21-2.

Key words: entomopathogenic fungi, antagonistic activity, phytopathogens, polyfunctional action, Beauveria, Isaria, Lecanicillium.

\section{Введение}

При разработке биопрепаратов для защиты растений одним из перспективных направений является создание продуктов, действующих одновременно и на возбудителей болезней растений, и на вредителей [1-3]. Результаты ряда исследований свидетельствуют о наличии антифунгального действия у энтомопатогенных грибов рр. Beauveria, Metharhizium, Lecanicillium [4-6]. В связи с этим актуальными являются поиск и селекция высокоактивных штаммов с комплексной фунгицидной и энтомоцидной активностью.

Целью настоящего исследования являлось проведение первичного скрининга энтомопатогенных микромицетов, выделенных из различных природных и антропогенных биоценозов на территории Беларуси, по уровню антагонистической активности в отношении тестовых культур фитопатогенов.
\end{abstract}

В 2021 г. было проведено маршрутное обследование природных и антропогенных биогеоценозов на территории Беларуси. С целью выделения микромицетов с комплексной активностью осуществляли сбор погибших насекомых с признаками микоза и образцов почвы, лесной подстилки и т.п. Выделение штаммов в чистую культуру проводили общепринятыми методами [7-8].

В условиях in vitro проведено изучение характера действия штаммов энтомопатогенных грибов на тест-культуры возбудителей болезней растений методом встречных колоний [9]. Посевы проводили на среду сусло-агар, культуры инкубировали при $27^{\circ} \mathrm{C}$. Анализировали показатели роста (диаметр колоний) фитопатогенных и энтомопатогенных микромицетов, отмечали образование стерильной зоны на границе контакта культур, рассчитывали ингибирование роста относительно контрольного варианта. В качестве контроля использовали чистые культуры штаммов [10].

Анализировали взаимодействие коллекционных штаммов возбудителей болезней растений Alternaria solani, Botrytis cinerea, Sclerotinia sclerotiorum, Rhizoctonia solani, Fusarium solani, Phytophtora alni и штаммов энтомопатогенных грибов, выделенных в результате поисковых исследований: Beauveria brongniartii MX, Beauveria sp. 4/21, Beauveria sp. 8/21, Isaria fumosorosea 21-2, I. fumosorosea I21, Lecanicillium sp. aph.

\section{Результаты и обсуждение}

В ходе наблюдений за динамикой развития микромицетов отмечено, что наличие антифунгального действия в разной степени было характерно для всех протестированных штаммов энтомопатогенных грибов. Антагонистическое действие энтомопатогенов проявлялось в снижении скорости роста фитопатогенных грибов и наиболее явно было выражено на 10-е сутки совместного роста в мо- 
мент непосредственного контакта колоний. Значения показателя ингибирования (относительное уменьшение диаметра колоний по с равнению с таковым при одиночном росте) варьировали от 2,7 до 60,1% в различных вариантах попарных сочетаний фито- и энтомопатогенов (таблица).

Таблица - Влияние энтомопатогенных грибов на рост тест-культур фитопатогенных грибов

\begin{tabular}{|c|c|c|c|c|c|c|}
\hline \multirow{3}{*}{$\begin{array}{l}\text { Тест-культуры фитопа- } \\
\text { тогенов }\end{array}$} & \multicolumn{6}{|c|}{ Сутки от начала опыта } \\
\hline & \multicolumn{2}{|c|}{ 3-и } & \multicolumn{2}{|c|}{$7-\mathrm{e}$} & \multicolumn{2}{|c|}{$10-\mathrm{e}$} \\
\hline & $\begin{array}{l} \pm \text { в \% к } \\
\text { контролю* }\end{array}$ & $\begin{array}{c}\text { стерильная } \\
\text { зона, мм }\end{array}$ & $\begin{array}{c} \pm \% \text { к кон- } \\
\text { тролю* }\end{array}$ & $\begin{array}{c}\text { стерильная } \\
\text { зона, мм }\end{array}$ & $\begin{array}{c} \pm \% \text { к кон- } \\
\text { тролю* }\end{array}$ & $\begin{array}{c}\text { стерильная } \\
\text { зона, мм }\end{array}$ \\
\hline \multicolumn{7}{|c|}{ Beauveria brongniartii $\mathrm{MX}$} \\
\hline Alternaria solani & $-60,1$ & - & $-38,1$ & - & $-40,7$ & - \\
\hline Botrytis cinerea & $-19,7$ & - & $-36,5$ & - & & \\
\hline Rhizoctonia solani & $-25,0$ & - & $-1,3$ & - & & \\
\hline Fusarium solani & $-18,9$ & - & $-33,8$ & 2 & & \\
\hline Phytophtora alni & $+26,2$ & - & $-38,7$ & 2,3 & & \\
\hline \multicolumn{7}{|c|}{ Beauveria sp. $4 / 21$} \\
\hline Alternaria solani & $-4,9$ & - & $-10,2$ & - & $-44,3$ & 2,8 \\
\hline Botrytis cinerea & - & - & $-8,9$ & 2,5 & & \\
\hline Rhizoctonia solani & $-15,4$ & - & $-26,3$ & - & & \\
\hline Fusarium solani & $-11,8$ & - & $-36,4$ & - & & \\
\hline \multicolumn{7}{|c|}{ Beauveria sp. $8 / 21$} \\
\hline Alternaria solani & $-3,0$ & - & $-15,6$ & - & & \\
\hline Botrytis cinerea & $+18,2$ & - & $-35,8$ & - & & \\
\hline Rhizoctonia solani & $+18,6$ & - & $-23,6$ & - & & \\
\hline $\begin{array}{l}\text { Sclerotinia scleroti- } \\
\text { orum }\end{array}$ & - & - & $+63,6$ & - & $+18,6$ & - \\
\hline Fusarium solani & $+13,1$ & - & $-26,9$ & - & & \\
\hline Phytophtora alni & $+33,3$ & - & $-48,0$ & - & & \\
\hline \multicolumn{7}{|c|}{ Isaria fumosorosea 21-2 } \\
\hline Alternaria solani & - & - & $-35,4$ & - & & \\
\hline Botrytis cinerea & $-17,6$ & - & $-38,4$ & - & & \\
\hline Rhizoctonia solani & $+37,7$ & - & $-32,2$ & - & & \\
\hline $\begin{array}{l}\text { Sclerotinia scleroti- } \\
\text { orum }\end{array}$ & - & - & $-2,7$ & - & $-41,5$ & - \\
\hline Fusarium solani & $-9,7$ & - & $-33,7$ & - & & \\
\hline Phytophtora alni & $+8,3$ & - & $-40,3$ & 1 & & \\
\hline \multicolumn{7}{|c|}{ Isaria fumosorosea $\mathrm{I} 21$} \\
\hline Alternaria solani & $+13,1$ & - & $-16,3$ & 1,5 & $-40,9$ & 1 \\
\hline Botrytis cinerea & $+72,6$ & - & $-28,3$ & 1 & & \\
\hline Rhizoctonia solani & $-21,6$ & - & $-21,6$ & - & & \\
\hline Phytophtora alni & $+4,2$ & - & $-7,9$ & - & & \\
\hline \multicolumn{7}{|c|}{ Lecanicillium sp. aph } \\
\hline Alternaria solani & $-7,7$ & - & $-17,4$ & 2 & $-30,9$ & 2 \\
\hline Botrytis cinerea & $-29,2$ & - & $-47,0$ & 3 & & \\
\hline Rhizoctonia solani & $-51,1$ & - & $-28,7$ & 3 & & \\
\hline Fusarium solani & $-7,1$ & - & $-40,8$ & 0,5 & & \\
\hline Phytophtora alni & $+15,7$ & - & $-35,7$ & 2 & & \\
\hline
\end{tabular}

Наибольший показатель ингибирования роста колоний по отношению к Alternaria solani выявлен у Beauveria brongniartii MX до 60,1 \%, по отношению к Botrytis cinerea (47,0 \%), у Lecanicil- 
lium sp. aph по отношению к Rhizoctonia solani (28,7 \%) и Fusarium solani (40,8 \%), у Isaria fumosorosea 21-2 к Sclerotinia sclerotiorum (41,5\%) и у Beauveria sp. 8/21 к Phytophtora alni (48,0 \%). Ингибирующее влияние энтомопатогенных грибов проявлялось также в формировании между колониями стерильной зоны. В наибольшей степени это было свойственно для штамма Lecanicillium sp. aph: образование стерильной зоны шириной от 0,5 до 3,0 мм было отмечено при попарном культивировании со всеми протестированными видами фитопатогенов.

\section{Выводы}

Сопоставление результатов определения антагонистических показателей новых штаммов энтомопатогенных грибов позволяет определить как перспективные для дальнейшего изучения как потенциальных биологических агентов полиф ункционального действия штаммы Beauveria brongniartii MX, Lecanicillium sp. aph и Isaria fumosorosea 21-2.

Работа выполнена в рамках задания «Получение штаммов микромицетов с энтомопатогенной и антагонистической активностью для создания биопрепаратов комплексного действия» ГПНИ «Сельскохозяйственные технологии и продовольственная безопасность».

\section{Литература}

1. GOETTEL, M.S., KOIKE, M., KIM, J., AUCHI, D., SHINYA, R., BROWDER, J. Potential of Lecanicillium species for management of insects, nematodes and plant diseases // J. Invertebr. Pathol. - 2008. - Vol. 98. - P. 256-261.

2. KIM, J.J. GOETTEL, M.S., GILLESPIE, D.R. Potential of Lecanicillium species for dual microbial control of aphids and the cucumber powdery mildew fungus Sphaerotheca fuliginra // Biol. Control. - 2007. - Vol. 40. P. 327-332.

3. OWNLEY, B.H., GWINN, K.D., VEGA, F.E. Endophytic fungal entomopathogens with activity against plant pathogens: ecology and evolution // BioControl. - 2010. - Vol. 55. - P. 113-128.

4. VANDERMEER, J., PERFECTO, I., LIERE, H. Evidence for hyperparasitism of coffee rust (Hemileia vastatrix) by the entomogenous fungus, Lecanicillium lecanii, through a complex ecological web // Plant Pathology. - 2009. - Vol. 58. - P. 636-641.

5. LOZANO-TOVAR, M.D, ORTIZ-URQUIZA, A., GARRIDO-JURADO, I., Trapero-Casas, A., QuesadaMoraga, E. Assessment of entomopathogenic fungi and their extracts against a soil-dwelling pest and soilborne pathogens of olive // Biological Control. - 2013. - Vol. 67, № 3. - P. 409-420.

6. ЧОГЛОКОВА, А.А., ПЕРВУШИН, А. Л., МИТИНА, Г.В. Антибиотическая активность и связь с морфолого-культуральными характеристиками природных изолятов грибов рода Lecanicillium // Современная микология в России. - 2015. - Т.4. - С. 312-314.

7. ЛИТВИНОВ, М.А. Методы изучения почвенных микроскопических грибов // Л. : Наука, 1969. - 124 с.

8. ЕВЛАХОВА, А.А. Энтомопатогенные грибы. Систематика, биология, практическое значение // Л. : Наука, 1974. - 260 с.

9. Методические указания к занятиям спецпрактикума по разделу «Микология. Методы экспериментального изучения микроскопических грибов» для студентов 4 курса дневного отделения специальности «G 310101 - Биология»/ авт.-сост. : В. Д. Поликсенова, А. К. Храмцов, С. Г. Пискун. Минск : БГУ, 2004. - 36 с.

10. Методы экспериментальной микологии: Справочник / И.А. Дудка [и др.]; под общ. ред. В.И. Билай. Киев : Наукова думка, 1982. - 550 с. 